\title{
Erratum to: Network-driven plasma proteomics expose molecular changes in the Alzheimer's brain
}

Philipp A. Jaeger ${ }^{1,2,3^{*}}$, Kurt M. Lucin ${ }^{1,17}$, Markus Britschgi ${ }^{1,18}$, Badri Vardarajan ${ }^{4}$, Ruo-Pan Huang ${ }^{5,6}$, Elizabeth D. Kirby ${ }^{1}$, Rachelle Abbey ${ }^{1}$, Bradley F. Boeve ${ }^{7}$, Adam L. Boxer ${ }^{8}$, Lindsay A. Farrer ${ }^{4,9}$, NiCole Finch ${ }^{10}$, Neill R. Graff-Radford ${ }^{11}$, Elizabeth Head ${ }^{12}$, Matan Hofree ${ }^{13}$, Ruochun Huang ${ }^{5,6}$, Hudson Johns ${ }^{1}$, Anna Karydas ${ }^{8}$, David S. Knopman ${ }^{7}$, Andrey Loboda ${ }^{14}$, Eliezer Masliah ${ }^{15}$, Ramya Narasimhan ${ }^{1}$, Ronald C. Petersen ${ }^{7}$, Alexei Podtelezhnikov ${ }^{14}$, Suraj Pradhan ${ }^{1}$, Rosa Rademakers ${ }^{10}$, Chung-Huan Sun ${ }^{1}$, Steven G. Younkin ${ }^{10}$, Bruce L. Miller ${ }^{8}$, Trey Ideker ${ }^{3}$ and Tony Wyss-Coray ${ }^{1,16^{*}}$

Unfortunately, after publication of this article [1], it was noticed that the name of Matan Hofree was misspelled. The corrected name can be seen above and the original article has been updated to reflect this change.

\begin{abstract}
Author details
${ }^{1}$ Department of Neurology and Neurological Sciences, Stanford University School of Medicine, Stanford, CA, USA. ${ }^{2}$ Institute of Chemistry and Biochemistry, Free University, Berlin, Berlin, Germany. ${ }^{3}$ Departments of Bioengineering and Medicine, University of California, La Jolla, San Diego, CA, USA. ${ }^{4}$ Department of Medicine (Biomedical Genetics), Boston University Schools of Medicine, Boston, MA, USA. ${ }^{5}$ RayBiotech, Guangzhou, China. ${ }^{6}$ RayBiotech, Norcrosse, GA, USA. 'Department of Neurology, Mayo Clinic, Rochester, MN, USA. ${ }^{8}$ Department of Neurology, University of California San Francisco, San Francisco, CA, USA. ${ }^{9}$ Departments of Neurology, Ophthalmology, Genetics and Genomics, Epidemiology, and Biostatistics, Boston University Schools of Medicine and Public Health, Boston, MA, USA.

${ }^{10}$ Department of Neuroscience, Mayo Clinic, Jacksonville, FL, USA.

${ }^{11}$ Department of Neurology, Mayo Clinic, Jacksonville, FL, USA.

${ }^{12}$ Departments of Pharmacology and Nutritional Sciences and Sanders-Brown Center on Aging, University of Kentucky, Lexington, KY, USA. ${ }^{13}$ Department of Computer Science and Engineering, University of California, La Jolla, San Diego, CA, USA. ${ }^{14}$ Genetics and Pharmacogenomics, Merck Research Laboratories, West Point, PA, USA. ${ }^{15}$ Department of Pathology, University of California, La Jolla, San Diego, CA, USA. ${ }^{16}$ Center for Tissue Regeneration, Repair and Restoration, VA Palo Alto Health Care System, Palo Alto, CA, USA. ${ }^{17}$ Present address: Biology Department, Eastern Connecticut State University, Willimantic, CT, USA. ${ }^{18}$ Present address: Roche Pharma Research and Early Development, NORD DTA, Roche Innovation, Center Basel, Basel, Switzerland.
\end{abstract}

Received: 11 May 2016 Accepted: 12 May 2016 Published online: 23 May 2016

\section{Reference}

1. Jaeger PA, Lucin KM, Britschgi M, Vardarajan B, Huang R-P, Kirby ED, Abbey R, Boeve BF, Boxer AL, Farrer LA, Finch N, Graff-Radford NR, Head E, Hofree M, Huang R, Johns H, Karydas A, Knopman DS, Loboda A, Masliah E, Narasimhan R, Petersen RC, Podtelezhnikov A, Pradhan S, Rademakers R, Sun C-H, Younkin SG, Miller BL, Ideker T, Wyss-Coray T. Network-driven plasma proteomics expose molecular changes in the Alzheimer's brain. Mol Neurodegener. 2016;11:31. doi:10.1186/s13024-016-0095-2.

\footnotetext{
* Correspondence: pjaeger@ucsd.edu; twc@stanford.edu ${ }^{1}$ Department of Neurology and Neurological Sciences, Stanford University School of Medicine, Stanford, CA, USA
}

\footnotetext{
Submit your next manuscript to BioMed Central and we will help you at every step:

- We accept pre-submission inquiries

- Our selector tool helps you to find the most relevant journal

- We provide round the clock customer support

- Convenient online submission

- Thorough peer review

- Inclusion in PubMed and all major indexing services

- Maximum visibility for your research
}

Submit your manuscript at www.biomedcentral.com/submit 